\title{
Marcin Kępiński*
}

iD https://orcid.org/0000-0003-4367-3224

\section{The wall of silence surrounding literature and remembrance: Varlam Shalamov's Artificial Limbs, Etc. as a metaphor of the soviet empire}

\begin{abstract}
The camp solitary confinement block was old and decrepit. It looked as if a wall might fall down, the whole block crumble, and the beams collapse, if you just knocked against a wooden cell wall. But the solitary confinement block wasn't going to fall, and the seven cell blocks went on doing their job. Of course, any word spoken loudly would be heard in the neighbouring cell. But those who were imprisoned there were afraid of being punished. ${ }^{1}$
\end{abstract}

The citizens of the USSR always feared punishment - sometimes more, sometimes less. They did not complain. They made sure not to displease the authorities. They kept silent. During the years of the Great Purge, people did not talk to each other in raised voices; they spoke quietly about insignificant matters and without giving any names. In public transport, on the underground, and in Moscow's streets you could not hear any conversations. Silence was pervasive. ${ }^{2}$ Some of the still free poets, e.g. Anna Akhmatova, burnt their poems so that they cannot fall into the hands of investigators, while imprisoned writers, e.g. Shalamov, were sentenced to be forgotten. ${ }^{3}$

* Professor of the University of Lodz, Ph.D. hab.; University of Lodz, Faculty of Philosophy and History, Institute of Ethnology and Cultural Anthropology; ul. Lindleya 3/5, 90-131 Łódź; marcin.kepinski@uni.lodz.pl

1 W. Szałamow, "Protezy", [in:] Opowiadania kołymskie, vol. II, trans. J. Baczyński, Wydawnictwo ATEXT, Gdańsk 1991, pp. 249-251. [English version: V. Shalamov, Komyla Tales, NYRB Classics, 2018.]

2 Vide: O. Figes, Szepty. Życie w stalinowskiej Rosji, trans. Wł. Jeżewski, Wydawnictwo Magnum, Warszawa 2008, pp. 215-266.

3 Vide: D. Szkoła, "Zakładniczka historii", [in:] Zmiany, metamorfozy, rewolucje, M. Czapiga, K. Konarska (eds.), Wydawnictwo Uniwersytetu Wrocławskiego, Wrocław 2018, pp. 25-35. 
I will not lie: Varlam Shalamov is one my favourite writers and I value his works highly. It is difficult for me to remain objective when it comes to his output. When I read him, I become immersed in an account of an autobiographical testimony, somewhat appropriating for myself (as a reader) the reality seen through his eyes and the recollections from the world of Kolyma.

Despite the harshness of the form - and an unwillingness to shock with strong emotional scenes or to moralise - the author of Kolyma Tales offered a faithful description of a world outside the 'human' world, one which was almost impossible to describe due to its inherent moral void, level of violence, and fear of the authorities. Kolyma remains in the book an ice-covered hell on Earth; closed Gulag space surrounded by a barbed wire fence; a void of death where no - not even the most basic - ethical principles survive, and the very mention of them seems inappropriate. Apart from being left to slowly die, its prisoners were sentenced to be forgotten, to stop existing, and the social recollections should retain a single mention of their existence. That sentence also applied to their biographies and their recollections about a world outside the wires of the Gulag zone, and about their loved ones, whom the authorities forced to renounce as the "enemies of the state"; with whom they had been before they were arrested and sent to Kolyma.

Resistance seemed futile. The carefully planned system of captivity did not allow for any rebellious movements against the state. Even loudly spoken words were banned. You had to keep quiet. Death itself was not the worst thing that could happen. Often it was a relief. What was the worst was captivity, and physical and mental suffering turning people into mindless flesh. When reading Kolyma Tales and the biography of Varlam Shalamov - a student of literature studies and a writer arrested and sent in the 1920s to the Solovetsky Islands for writing about freedom - it comes as no surprise that the word 'soul' was forgotten in Kolyma. What counted there was survival, sometimes even at any price. It would be difficult to find a prisoner who would have enough courage and spiritual power to oppose the deprivation. That was depicted perfectly by Shalamov in his short story titled Artificial Limbs, Etc.

The value of literature is its ability to enable people to convey through words - and consolidate in the social memory - the testimonies, thoughts, and feelings in a way which is inaccessible for other art forms. Literature of an autobiographical character acquires a special significance in the world of the bloody and tragic events of the $20^{\text {th }}$ century, i.e. the Holocaust, the Second World War, the realities of the Nazi and Soviet totalitarianisms, death camps, and forced labour. Those are the recollections of experienced trauma which shatters identity, and of existential experiences of a borderline nature, of which Shalamov - a witness to the epoch - felt an obligation to talk. 
According to Magdalena Marszałek, a testimony

is a form of communication which consists of an account of past events offered by their participant (as an onlooker, actor or victim), i.e. referring to personal memory. In its basic meaning, a testimony, being an autobiographical confirmed description of a past event ("I was there"), also constitutes an element of everyday communication based on trust in the other person's words. (...) The theory of the testimony which has been developing since the 1980s - as part of the studies into the Holocaust and its aftermath - also defined a new form of an account which emerged as a result of the 2oth-century systems of terror and genocide. ${ }^{4}$

Literature, mostly autobiographical, can be treated as a medium of remembrance, as one of its carriers and the object of cultural memory, which is vital for groups and entire societies. ${ }^{5}$

The 1980s in particular, filled with recollective literature and related to the transformations of the culture of remembrance, elevated the importance of literature as a form of testimony. ${ }^{6}$

In the case of Varlam Shalamov's output, autobiographical works are also culturally significant not only considering their topics covering areas important for social memory, but even the very autobiographical pact understood as a culturally significant convention of writing and reading, enabling people to retain and recall personal narratives of the experienced world reconstructed in recollected images. ${ }^{7}$ In addition to that, Shalamov was a moral witness, i.e. - according to the culture of remembrance - someone who himself experienced trauma not as an onlooker but as a participant of dramatic events. As a survivor, he "testifies for those who perished, in a sense giving them a chance to speak." "What is also important is the need to have someone other who takes the testimony of a victim and feels the obligation to inform others about the experienced dramatic trauma. Such narratives continue to circle around tragic experiences, establishing a framework of remembrance and a part of the process of coping with trauma. This experience - "fundamentally inexpressible, impossible to represent" - is, at the same time, as

4 M. Marszałek, "Świadectwo", [in:] Modi memorandi. Leksykon kultury pamięci, Wydawnictwo Naukowe Scholar, Warsaw 2014, p. 473. [Unless indicated otherwise, quotations in English were translated from Polish.]

5 Vide: K. Trybuś, "Literatura", [in:] Modi memorandi..., pp. 205-210.

6 Vide M. Marszałek, "Autobiografia”, [in:] Modi memorandi..., p. 57.

7 I discussed autobiographical literature and its relationships with autobiographical memory in detail in: Pomiędzy pamięcia autobiograficzna a zbiorowa. Polska Ludowa i stan wojenny w narracjach łódzkich nauczycieli, Wydawnictwo Uniwersytetu Łódzkiego, Łódź 2016, pp. 72-82. M. Marszałek, "Świadectwo", [in:] Modi memorandi..., p. 475. 
Assmann described it (1999), "a stabiliser of memory" and "the ally of testimony driving the speaking." "When reading Kolyma Tales, one infers that somewhere in the background of the narrative there is a sense of an obligation to talk (i.e. to offer testimony), which accompanied the author. This was probably, I believe, the reason for the writer's particular mode of narrative, i.e. in the simplest form and with the choice of the simplest stylistic devices, giving an impression of simplicity - if not a lack of emotions - in depicting the Kolyma reality.

Finally, Kolyma Tales constitutes

most of all a testimony. And V. Shalamov was a "privileged» witness as he observed the birth of the Gulag empire serving his sentence at the 4th Department of SLON - Soviet Special Gulags, at the Vishera Gulag, where at the construction site of the foundations of the Soviet industry, at communism's first construction sites the state first experimented with the operation of the new Gulag system, a grand experiment of deprivation of the human soul, later expanded to cover the whole country. ${ }^{10}$

Shalamov's style was economical, dry even, devoid of any sophisticated linguistic devices. When compared to his mode of narrative, Tadeusz Borowski's Auschwitz short stories seem almost Baroque in style. In my opinion, Gustaw Herling-Grudziński's style of writing was the closest to Shalamov's style. It was Herling-Grudziński who added his own short story to Kolyma Tales, one titled Piętno. Ostatnie opowiadanie kołymskie [Stigma: The Final Kolyma Story], in which he proposed his imagined vision of Shalamov's death and burial. It stated that:

A young man stepped in front of a circle of people. He approached the coffin, lifted a candle which flickered in his eyes, and he spoke in a resonant voice: «Kolyma etched its words on each face, it has left its mark, it carved out additional wrinkles, it has impressed an eternal stigma, an indelible, ineffaceable stigma!» That was a passage from a short story by the Grand Writer entitled Cisza (...) The future biographer of the Grand Writer is surely going to commend the choice of the farewell passage made by the young man. It is a unique instance in the author's output who, as everyone knows, avoided unnecessary words and was wary of exclamations."

This was what Varlam Shalamov was famous for - that ability to write in a seemingly dispassionate and cool manner about a time, events, and things which were extremely inhuman, terrible, and not conveyable experiences of that trauma.

9 Ibid., p. 476.

10 M. Heller, "Przedmowa do pierwszego wydania rosyjskiego", [in:] W. Szałamow, pp. VIII-IX.

11 G. Herling-Grudziński, "Piętno. Ostatnie opowiadanie kołymskie”, [in:] W. Szałamow, pp. 275-276. 
Probably it would not be possible to write Kolyma Tales in any other way. How could you write about the reality of hell? The freezing hell of Kolyma's mines, cold like the second ring of infernal torment in Jacek Kaczmarski's song. ${ }^{12}$ The Kolyma as seen and described by Shalamov was an underground infernal world: "Even after reading the first few short stories, you want to say: its hell, the final stage of hell. Even Shalamov wrote himself: «I was coming back from hell» (The Train). It seems that there could not be anything worse than hell." ${ }^{\prime 3}$ With one exception, i.e. that in Kolyma the punishment was not a triumph of justice but, rather, of lawlessness, and it concerned not sinners but people who were innocent.

The short story titled Artificial Limbs, Etc. contains the entire terrifying and raw beauty of Varlam Shalamov's prose. There are, of course, internees, GULAG prisoners and their supervisors, and camp guards, i.e. NKVD officers. Victims and tormentors, so different and yet similar citizens of the USSR (prisoners deprived of their rights versus guards who still have theirs), a country of lawlessness applied in line with the communist law. A huge country with the world's biggest camp system of forced labour and death. A country of people's democracy surrounded by walls, barbed wire, vigilantly guarded borders, and with a several-million-strong army of the system of coercion and repression. Anne Applebaum thus described the guards of camp zones, forced to join the system of repression after the Second World War: "Nor could they easily leave (of the guard duty at Gulags - M.K.). Many had been deprived of their documents - passports, residence permits, military service certificates. Without them they were unable to leave the camps, let alone search for new jobs. Between 300 and 400 every year committed suicide. (...) Others simply degenerated." ${ }^{\prime 14}$

In the discussed short story, the citizens of the Soviet Union - stripped of their civil rights and sentenced based on the infamous Art. 58 - were incarcerated at one of the GULAG camps in the far north of the USSR. Sent to solitary confinement to serve an additional penalty, i.e. a prison within a prison, they were subjected to an inspection procedure. They had to give up their prosthetic limbs one by one. Among the prisoners being readied for another show trial, there were only enemies of the people sentenced for crimes against the Soviet state. There was a snitch

12 In a fragment of a well-known song by Jacek Kaczmarski Epitafium Dla Włodzimierza Wysockiego [Epitaph for Vladimir Vysotsky], the second circle of hell was the GULAG reality:

Those sent! Those sent!

Marked, condemned, and sold!

What are you doing in the mines of hell

Wading in mud, trampling ice!

Is death once again sending free people

Under the knout!?

13 M. Heller, op. cit., p. IX.

14 A. Applebaum, Gułag, trans. J. Urbański, Świat Książki, Warsaw 2005, p. 259. [English version: A. Applebaum, Gulag: A History of the Soviet Camps, Doubleday, New York 2003.] 
among them as well as an old communist, a veteran of the civil war, a former member of Budyonny's forces. He was not going to willingly give up his prosthetic arm and he struggled with the guards. There was a deaf prison doctor, also a prisoner, an old man freely giving up his ear trumpet. The next one was a representative of the extinct (or rather exterminated) class of Russian gentry, who lost his leg at the front of the First World War. He gave up his prosthetic leg and, jumping on the other, entered a solitary cell on his own. Finally, a brigade leader and a prisoner had to give his glass eye:

While they were recording Grisha's eye, the chief of the solitary block suddenly became merry and couldn't stop giggling.

«So, one man gives me an arm, another a leg, another an ear, another his back, and this one his eye. We'll collect a complete body. And how about you?» He carefully looked over my naked body.

«What are you going to hand over? Your soul?»

«No,» I said. «I won't let you have my soul.» ${ }^{15}$

I believe one could view this fragment as a description of the failed experiment to create the new Soviet human being who - like the mythical Golem - could not exist without a soul. But communism did not allow anyone to believe in the existence of the soul while trying hard to create an ersatz soul, as aptly indicated by Aleksander Wat.

It is possible that Shalamov saw the soul still rattling around inside the starved, the tormented, and the humiliated body of the internee as a kind of a prosthetic devoid of internal strength and resistance due to the harm that was being inflicted.

The guards were the oppressors of the prisoners, tormenting the "enemies of the people", at the orders of the camp chief putting them into solitary, stripping them naked and taking away their prosthetics along with their clothes. Yet the masters of the prisoners' life and death were also the inhabitants of Kolyma. It did not matter that they chose to serve the communist regime, since they were forced to remain at the camp and, possibly, just like the prisoners, they would never leave it. They too spent their lives locked up in the far north. Artificial Limbs, Etc. offers an image of the camp, naturally, with barbed wire, turrets, guards, the bosses having absolute power over the zeks. All of them - both the guards and the prisoners - were locked in a communist paradise, unable to escape, as if behind a tall wall. In fact, even 'free' citizens of the USSR faced the danger of being locked. As was Shalamov, sentenced to remain in the USSR until his dying days. Nothing changed once he emerged outside the walls of the prison and the camp zone, when he was no longer in solitary. He was still inside a bigger prison, as this was the way the 
USSR was perceived by a mass of ordinary citizens. For him, that larger prison was even worse and more difficult to endure as not only did he realise the physical and mental isolation, but he was also aware of the fact of the existence of the wall of silence and obliviousness surrounding the victims, i.e. the witnesses of the tragedy of Gulags.

Before finding themselves behind the prison walls and camp wires, both the guards and the prisoners in Artificial Limbs, Etc. were the inhabitants of cities and villages of a country tightly wrapped with a wall preventing them from stepping outside it. Mind you, apart from the actual wall, there was still the mental wall erected due to the changes in people's identities and attitudes, and the changes to the values, standards, and the culture which existed in the Soviet State. Those changes applied to both the guards and the prisoners. This is why I believe it is necessary to pay particular attention to the fact that Artificial Limbs, Etc. features the word 'soul'.

It is used only once - clearly and emphatically - as a metaphor of freedom throughout Shalamov's output. ${ }^{16}$ The author avoided moralising, the evaluations of the actions of prisoners and their supervisors, the roles of tormentors and victims, or the impact of the communist system dreadfully deforming the soul. This very short, only three-page-long short story was the only one in which the author used the word referring to the existential condition of an individual facing a borderline situation of utter humiliation, stripping them of their last pieces of freedom. Yet 'soul' in the short story is not complete freedom as that was not possible in the Stalinist state. Rather, it was autonomy. This is also why I believe that Shalamov acted purposefully in using that word and giving his short story the title Artificial Limbs, Etc.

Prison and camp wires were not the only kinds of walls erected by communism. There was still the barrier established around memory; autobiographical memory in the case of Shalamov and other writers, such as Aleksandr Solzhenitsyn, who wrote about the labour camps in the USSR, which was expressed in recollective literature, in its autobiographical variant. Apart from silence - because to speak the truth about Gulags was punishable by imprisonment (the infamous article on anti-Soviet agitation) - Shalamov's life and works also include a clearly visible wall of preventive censorship, typical of totalitarian systems. This was the reason why Kolyma Tales was published in the West and the writer was harassed for the collection until his death in 1982. Fortunately, also in this case the walls fell, though they lasted at least as long as the USSR persevered.

16 The word 'soul' also appeared in Shalamov's other short stories, e.g.: Carpenters, Quiet, Dry Rations. Yet in those, it does not take on such a key importance as in Artificial Limbs, Etc. Shalamov told the tragedy of a prisoner, a pastor forgetting the names of the Apostles under the influence of his terrible experiences at the Gulag in the short story titled The Apostle Paul. 
When compared to Shalamov's prose, the existential musings of Kierkegaard, Sartre, or Camus seem dull. His short story could be read in different ways. One could see in it a metaphor of the Soviet empire, which was built on fear, harm, and violence. The Gulag solitary confinement was prison within a prison, an internal camp intended for internees who - according to the bosses - dared to commit crimes in violation of the camp rules and regulations or who were supposed to be the subjects of investigations. It seemed as it was going to fall apart as it was old and carelessly built. Nothing of that sort. It persevered and no one dared to verify its structural integrity. The solitary confinement was actually a huge country surrounded by barbed wire with people securely locked inside and humiliated by the state. People behind the wires felt fear; they were afraid of punishment for louder whispers, which could be heard by other inmates or even the supervisors. Actually, the supervisors themselves were also prisoners; they had more privileges, but they could not leave the Gulag as well. From the grand medium-security camp, citizens could at any moment end up in the internal zone, i.e. the labour camp. Thus, it was better to keep quiet and not say anything; keeping quiet would not save them from state violence or fear, but it would help them endure.

The short story is also a metaphor of overwhelming terrible captivity by Stalinism experienced by Soviet citizens, as well as those inhabiting the satellite states of the socialist bloc, resembling a Stalinist solitary confinement. Hence, probably, the title: Artificial Limbs, Etc. The soul which the protagonist refuses to surrender is basically nothing more than a prosthetic of the soul deprived and murdered by the inhumane system of the Soviet totalitarianism. In fact, the Soviet human, created through the perekovka of the soul, was only a prosthetic of humanity. In Stalinist Russia, no one could have a free soul, especially not the prisoners of the Kolyma Gulag. The rulers of the Soviet State striving for communism acted per the rule: let us deprive people of that which makes them something more than an animal satisfying their instincts and we will turn them into slaves who do not realise they had been enslaved. Let us deprive them of their identity, religion, values, and the will for moral resistance, and we will create a prosthetic of humanity - a prosthetic of the soul.

The human in such a situation," according to Paweł Śpiewak reflecting on the memory of communist, "is no longer able to refer to things, and most of all the know themselves. Between «him/her» and «himself/herself», not to mention other people and images of the world, there exists a chasm. Not being able to refer and describe himself/herself, they are left with self-definitions suggested only by their instincts and passions which lead them, govern them, and determine them. They thus become man of hunger, and yearning for sex and sleep. They only wish to satiate those hunger-ridden creatures. They are reduced to experiencing pain and moments of happiness. All spiritual sensations are no more. They can be controlled and ruled by allowing them to live, sleep and eat. They are mere biology and physiognomy 
controlled from the outside which on top of that, being driven by fear of death and extermination, refers to the world using mathematicised rules, against any facts. ${ }^{17}$

Aleksander Wat spoke in a similar vein when he referred to the totalitarian extraction of the soul as a reduction of the human by taking away the human ability to reflect on oneself and on the surrounding world:

The essence of Stalinism is the poisoning of the internal human being in man to reduce him, like those tiny heads made by head hunters, those tiny dried heads, and then so that it completely not so much rots in man, as communists are afraid of internal decay, but rather crumble into dust. (...) To introduce the communist ten commandments into the soul it is necessary to murder the internal man. ${ }^{18}$

That re-forging of the soul enabled the shattering of family and social bonds, setting children against their parents or wives against their husbands. Social structures - even the smallest ones, e.g. the family - remained under strict monitoring of the system of rule and terror. In the totalitarian world, an act of denunciation (even against one's loved ones) was a virtue, while an act of trusting others was a mistake which resulted in internment at a labour camp or prison. This is why Varlam Shalamov never trusted any of his fellow inmates enough to discuss with them the topics banned by the authorities. Even he experienced the wall of solitude which communism erected around the citizens of the USSR. When serving his first sentence at Butyrka prison, he understood that the attitude of alienation and internal immigration would help him endure: "Here, it became possible to understand once and for all and to feel with the entire body, entire soul, that solitude is the optimal human condition."' In fact, even the end of the Gulag internment was not the end of the hell of the writer's life in the Soviet Union. The wall of solitude and the lack of trust between people caused by communism persisted, forever etched into the reality of the USSR: "After leaving the Gulag, Shalamov lost his family. His daughter did not want to know him, she renounced him. His wife got a divorce. The Gulag had its extension in the society even without the barbed wire." ${ }^{20}$

Somewhat naturally, Kolyma Tales, both in the sphere of content and form, constitutes a polemic with The Gulag Archipelago. It seems that Solzhenitsyn

17 P. Śpiewak, Pamięć po komunizmie, Wydawnictwo słowo/obraz terytoria, Gdańsk 2005, p. 14.

18 A. Wat, Mój wiek. Pamiętnik mówiony. Rozmowy prowadził i wstępem opatrzył Czesław Miłosz, part 1, Czytelnik, Warsaw 1990, p. 241.

19 W. Szałamow, Wiszera. Antypowieść, trans. J. Baczyński, Czytelnik, Warsaw 200o, p. 6.

20 G. Herling-Grudziński, P. Sinnatti, A. Raffetto, "Zapamiętane, opowiedziane. Rozmowa o Szałamowie", trans. J. Ugniewska, [in:] W. Szałamow, Wiszera..., p. 256. 
believed in the "Russian soul", while Shalamov remained an atheist, and for him any form of moralising or philosophical debates was strange. Varlam Shalamov

emphatically rejected didacticism or moralising in art while accusing $19^{\text {th }}$-century Russian writers of «each and every one of them acting as a teacher while the strictly literary objective and discoveries have been since Belinsky considered as things of a secondary importance». (...) A polemic with Aleksandr Solzhenitsyn was inevitable and it did occur. For Shalamov, Gulag was hell (its ninth circle) destroying internees physically and morally, while for the author of The First Circle, certainly closer in his thinking to the concepts by Fyodor Dostoevsky and Lev Tolstoy, it was a test of character from which internees could emerge victorious (e.g. thanks to faith). The total overwhelming pessimism clashed in that case with metaphysical and utopian optimism. ${ }^{21}$

Attempts at celebrating the Russian soul can be found in, e.g., One Day in the Life of Ivan Denisovich, while Shalamov indicated the "borderline beyond which all souls fall apart (...) He showed that suffering does not enrich people (Dostoevsky's argument), rather makes them indifferent, and the line between victims and oppressors becomes blurred (...)."22 In the discussed dispute over the soul (not only Russian), it is Shalamov who seems to be right. After years spent no longer in a labour camp but out of prison, life in the Soviet Union seems to have added the plot of the final Kolyma Tale. By the end of his life, the writer was relocated to an old people's home, where his patterns of behaviour which he had developed in Kolyma - and which were described in the already mentioned short story by Gustaw Herling-Grudziński - surfaced. A medical commission determined it was necessary to relocate Shalamov to a psychiatric hospital, where he eventually died of pneumonia in 1982. As Tadeusz Klimowicz wrote: "His final moments were witnessed by a «sitter» (a person collaborating with the NKVD and later with KGB - M.K.), who accompanied him since the beginning of his stay at the psihushka."23 While he was still alive, the Soviet state erected around the writer a wall and retained it after his death, sentencing his greatest work, i.e. Kolyma Tales, to be completely forgotten. Surely, the death of the disloyal witness to the history of Kolyma's Gulag hell pleased the Soviet authorities. Apparently, literature can come close to reality in a tragic and unimaginably true manner. George Orwell fought in the Spanish Civil War, viewing the front-line cruelty from up close. He also witnessed how the revolution devoured its own children and the armed conflict between anarchists and Stalinists. The highest priest of the

21 T. Klimowicz, Przewodnik po wspótczesnej literaturze rosyjskiej i jej okolicach (1917-1996), Towarzystwo Przyjaciół Polonistyki Wrocławskiej, Wrocław 1996, p. 663.

22 T. Klimowicz, op. cit., p. 663.

23 Ibid., p. 664. 
New Faith ${ }^{24}$ could not stand apostates and heretics amongst the revolutionary forces. The order to purge their midst of anarchists and Trotskyists, enacted by NKVD agents, was a major cause of the failure of the republicans. That might have been one of the reasons why Arthur Blair, a volunteer in the POUM forces, became a prophet of total surveillance of the Stalinist model of the state. World without higher feelings or morality, built by totalitarian ideology, was discussed by O'Brien, a member of the Inner Party, the brain-washed protagonist of Nineteen Eighty-Four:

Power is in inflicting pain and humiliation. Power is in tearing human minds to pieces and putting them together again in new shapes of your own choosing. Do you begin to see, then, what kind of world we are creating? (...) A world of fear and treachery and torment, a world of trampling and being trampled upon, a world which will grow not less but more merciless as it refines itself. (...) In our world there will be no emotions except fear, rage, triumph, and self-abasement. Everything else we shall destroy - everything. ${ }^{25}$

Any higher emotions must be reduced as they interfere with the proper functioning of the citizens of a totalitarian state.

To rule people, fear and absolute control over their bodies and minds is not enough. It is also necessary to rule the past which exists in recollections and recorded documents. This was why Shalamov was forced to condemn his own work, which he had published abroad. Books and documents can be easily destroyed or changed so that they are in line with the current version of the truth. That was the task fulfilled by the protagonist of Orwell's novel - his task was to correct the errors in the records of past events. Yet it is much harder to change the recollections of a witness to a tragedy, those which are stored in individual memory, especially if they are glaringly contrary to the official state-enforced version of the past and its interpretation.

Jacques Le Goff noted: "To make themselves the master of memory and forgetfulness is one of the great preoccupations of the classes, groups, and individuals who have dominated and continue to dominate historical societies. The things forgotten or not mentioned by history reveal these mechanisms for the manipulation of collective memory." ${ }^{26}$ Totalitarian societies easily yield to the temptation of manipulating memory.

24 I used this term after Czesław Miłosz, vide idem.: Zniewolony umysł, Wydawnictwo Literackie, Krakow 1999.

25 G. Orwell, Rok 1984, trans. T. Mirkowicz, Państwowy Instytut Wydawniczy, Warsaw 1998, p. 184. [English version: G. Orwell, Nineteen Eighty-Four, (p. 364), Kindle Edition]

26 J. Le Goff, Historia i pamięć, trans. A. Gronowska, J. Stryjczyk, Wydawnictwa Uniwersytetu Warszawskiego, Warsaw 2007, p. 104. [English version: J. Le Goff, History and memory, Columbia University Press, New York 1992.] 
Mind you, communism as a political system featured

the abolishing of any democratic freedoms, persecutions of religions and the clergy, forced collectivisation, «building of socialism» not paying any attention to economic conditions with all the consequences of that - all those elements triggered social tensions which were countered with widespread terror. (...) Destruction in the name of construction; hatred towards people considered enemies, who were stripped of any human qualities (rats, nits, pigs, dogs, stinking carcass, vultures), who were trampled down in the name of «humanism»; lies in the name of «truth» of which the party was the sole purveyor; captivity in the name of social and national liberation; totalitarian dictatorship in the name of «true democracy» - all that created the forged image of the world which has not been completely corrected until this very day. ${ }^{27}$

Revolutions and revolutionary social changes not only shatter the walls of prisons, e.g. Bastille, but they also erect new ones, replacing truth with lies. Revolutions require an enemy, hence walls between social groups, cultures, and entire societies (the us-them dichotomy, the figure of the enemy). According to the Marxist ideology, the inevitable development of the class struggle was the reason why the communist revolution eventually found enemies in the citizens of the state created by the Soviet authorities. By erecting walls, revolutions create social memory anew, expunging from its scope entire areas and replacing them with completely new ones. Changes apply to dates of past events considered important along with their interpretations, symbols, and the language and its references which we use to describe the past. Some events are forgotten, while others are introduced into the canon of social memory. Changes apply to normative models and cultural traditions, and even names of cities and months. Changes in the memory which applies to the past of a community, introduced by the authorities, "depend on the changes in school history or literature curricula, changes of street names, toppling some monuments and erecting new ones, and the creation of new works of literature or films (...) which interpret the past differently." 28 Thus, the authorities erect walls not only around literature, but also around memory.

Maurice Halbwachs noted that in order to maintain a sense of social generational continuity, identification with a community - as well as to retain common collective identity - it is necessary to apply the process of forgetting and correcting memory:

27 K. Kersten, "Wstęp do polskiego wydania", [in:] St. Courtois, N. Werth, et al., Czarna księga komunizmu, Prószyński i S-ka, Warsaw 1999, p. 11.

28 M. Golka, Pamięć społeczna i jej implanty, Wydawnictwo Naukowe Scholar, Warsaw 2009, p. 123. 
Society from time to time obligates people not just to reproduce in thought previous events of their lives, but also to tough them up, to shorten them, or to complete them so that, however convinced we are that our memories are exact, we give them a prestige that reality did not possess. ${ }^{29}$

When reconstructing their past, groups which form a society alter it. This is inevitable, like the passage of time, like acid slowly eating through a society's frameworks of memory. These are not invariable, though they are much more durable than the recollections of individuals of small groups:

The frameworks of memory exist both within the passage of time and outside it. External to the passage of time, they communicate a bit of their stability and generality to the images and concrete recollections of which they are made. But these frameworks are in part captivated by the course of time. They are like those woodfloats that descend along a waterway so slowly that one can easily move from one to the other, but which nevertheless are not immobile and go forward..$^{30}$

In the name of maintaining its collective identity and social continuity of generations, a society demands the sacrifice of recollections which do not fit the collective memory. It is the group that has the advantage over an individual as a society yields measures for recreating memory. At this point - which once again directs us towards the authorities as a form of domination over an individual - there emerges a danger of manipulating the content of social and cultural memory.

The authorities eagerly utilise ideology and institutions which enable them to maintain their supremacy. This points towards the sphere of politics of memory. Social memory subjected to manipulation is nothing other than images of the past delimited by a wall, permitted and approved by the authorities. Outside it, there lies the land of oblivion.

Paul Ricoeur associated manipulated memory with forgetting and ideology: "every thing that compounds the fragility of identity also proves to be an opportunit for the manipulation of memory, mainly through ideology." ${ }^{31}$ Abuses of memory are also abuses of forgetting, which selectively approaches narratives. A particular temptation to manipulate memory applies to the memory of communities and groups, to their collective identities:

29 M. Halbwachs, Społeczne ramy pamięci, trans. M. Król, Wydawnictwo Naukowe PWN, Warsaw 2008, p. 171. [English version: M. Halbwachs, On Collective Memory, University of Chicago Press, Chicago 1992.]

30 Ibid., p. 421.

31 P. Ricoeur, Pamięć, historia, zapomnienie, trans. J. Margański, Universitas, Kraków 2007, p. 590. [English version: P. Ricoeur, Memory, history forgetting, University of Chicago Press, Chicago 2004.] 
the prime danger (...) lies in the handling of authorized, imposed, celebrated, commemorated history - of official history. The resource of narrative then becomes the trap, when higher powers take over this emplotment and impose a canonical narrative by means of intimidation or seduction, fear or flattery. A devious form of forgetting is at work here, resulting from stripping the social actors of their original power to recount their actions themselves. ${ }^{32}$

Ricoeur indicated that the fact of removing the right and ability to a narrative about oneself and the world - so also about our past and the past of our community - cannot occur without our participation. This is clear in the case of "forgetting through avoidance (fuite), the expression of bad faith and its strategy of evasion motivated by an obscure will not to inform oneself, not to investigate (...) by a wanting-not-to-know." ${ }^{33}$ We wish to remember neither the pain of the victims nor our complicity. This is an active form of forgetfulness. Avoidance as a form and strategy of remaining oblivious, according to Ricoeur, entails the same kind of responsibility as intentional negation of memory. One should at least try to learn the truth about the past (or tell it as a witness), which differs from the official version of the narrative imposed by the authorities. One should not be surprised by the lapses in the memories of the oppressors, as Shalamov indicated in his short story titled The Procurator of Judea. Therefore, one should pay even more attention to the wall of silence erected by the Soviet state around the autobiographical recollections of former internees. In the case of Varlam Shalamov and his greatest work, the forced forgetting became the writer's personal tragedy, being a huge blow for the truth both about the trauma of Kolyma Gulags and about the Soviet system breaking spirits and stripping individuals of their freedom.

Artificial Limbs, Etc. raised an important existential problem of the opposition to the taking-away of memory and the remnants of freedom in a captive world, the rejection of a materialist philosophy used by the constructors of communist walls for creating a world of totalitarianism which enslaved individuals and for transforming that individual into a slave without a soul. It is about the refusal to accept the walls erected around the recollections of a witness to trauma, and around literature as a medium for communicating autobiographical memory.

When reading Shalamov's short story, I had the thought about resistance, born of despair, towards the fact of stripping people off the last pieces of their freedom in a situation of extreme humiliation exacted by the communist Stalinist system. A thought about rebelling against the totalitarian oppression was doomed to fail from the very beginning, which the protagonist of Varlam Shalamov's prose knows. It is about a thought about the unique role of literature understood as a remedy 
for captivity and the fact of taking away the right to talk about the recollections of experienced trauma. About truth. A thought about the soul as a metaphor of everything which people cannot give up if they wish to retain at least a morsel of freedom. I was not the only one who read Artificial Limbs, Etc. this way. This is what Gustaw Herling-Grudziński, another witness to the terrible events of the $20^{\text {th }}$ century, wrote about it:

I remember a beautiful short story Artificial Limbs, Etc. One day at the camp, functionaries confiscate from the internees all their prosthetics, wooden legs and hands, steel corsets, fake teeth, etc. When the time comes for Shalamov, the soldier who was supposed to collect them asked him: «And how about you? Your soul?» Shalamov answered: «I won't let you have my soul.» That is a terribly categorical statement. That was the end of the very concise short story. And that was extremely telling. (...) Shalamov talked to his own soul and the souls of others through literature. Thus, he defended a certain virtue, i.e. humanity, which was inside him, and he did that in an intense form. ${ }^{34}$

Relatively few Gulag internees participated in the struggle against the communist system, the system of Gulags, and the system of distorting memory in which Varlam Shalamov was engaged by remembering and giving his testimony: "Obviously, people who did not survive did not write. Those who were mentally or physically damaged by their camp experiences did not write either." ${ }^{35}$

The trauma of the experienced nightmare and a fear of it returning was the reason why the victims of Gulag were reluctant to testify. This was why all that some of them wanted to do was to forget about the Gulag: "Cowed and silenced, the majority of Stalin's victims stoically suppressed traumatic memories and emotions. «A human being survives by his ability to forget,» wrote Varlam Shalamov in Kolyma Tales. People who had suffered terribly did not talk about their lives. They very rarely cried." ${ }^{36}$

Fear was the reason why people remained vigilant and kept quiet as no one knew how long the thaw period which began with the famous speech by Khrushchev would last. Even at its peak in the 1960s - when Stalin's remains were removed from the Lenin Mausoleum and when Kaganovich, Molotov, and Malenkov were removed from the party - the state retained its totalitarian traits. No one commemorated the millions murdered, no one officially apologised to those victimised, and there was no redress. The thaw ended when Brezhnev came to power; he once again hailed Stalin as the grand chief and aggravated the Party's approach

34 G. Herling-Grudziński, P. Sinnatti, A. Raffetto, op. cit., p. 271.

35 A. Applebaum, op. cit., p. 328.

36 O. Figes, op. cit., p. 514. [English version: O. Figes, The Whisperers, Picador, New York 2008] 
towards dissidents who demanded their right to memory and truth. Fear accompanied the victims of Gulags until their dying days. ${ }^{37}$

This is why the attitudes of the dissidents who - like Varlam Shalamov - fought for the right to remember is even more impressive.

In the penultimate stanza of Epitafium dla Włodzimierza Wysockiego, Jacek Kaczmarski sang:

I pojąłem co chcą ze mną zrobić tu!

I za gardło porywa mnie strach!

Koń mój zniknął, a wy, siedmiu kręgów

tłum,

Macie w uszach i w oczach piach!

Po mnie nikt nie wyciągnie okrutnych

rąk,

Mnie nie będą katować i strzyc!

Dla mnie mają tu jeszcze ósmy krąg!

Ósmy krąg, w którym nie ma już nic.
And I understood what they want to do to me!

And fear grasps my throat!

My horse is gone, and you, the crowd of the seven circles,

Have sand in your ears and eyes!

No one will reach for me with their cruel hands,

No one will torment me or shave my

head!

For me they have an eighth circle!

The eighth circle where there is nothing no more.

In the eighth circle of the Soviet empire there are no disobedient writers or literature, nor is there a soul. No one remembers about them. What is left is emptiness and the void of forgetfulness, which is a true hell for an artist. There is a silent and blind crowd of slaves. The only hope is to retain one's recollections and to pass them onto others. This is the role of poets of the permafrost and of Gulag internees, such as Varlam Shalamov. There was a reason why Jacek Kaczmarski concluded his song about Vladimir Vysotsky in the following stanza:

Pamiętajcie wy o mnie co sił! Co sił!

Choć przemknąłem przed wami jak cień!

Palcie w łaźni, aż kamień się zmieni w pył -

Przecież wrócę, gdy zacznie się dzień!
Remember me with all your strength!

With all your strength!

Though I passed in front of you like a shadow!

Burn at the baths, until the stones turn to dust -

I will return when the day starts!

37 Orlando Figes wrote about this in The Whisperers... in a chapter devoted to the recollections of camp trauma and the further fortunes of the victims of Gulags. Vide: idem., op. cit., pp. 506-555. 
Fortunately, forgetfulness - being the result of distorted memory, fake past, and a kind of totalitarian politics of memory - did pass along with totalitarianism. And so, the memory of the witness to the hell of Kolyma - and his literary narrative, his testimony - survived the night of the Soviet empire.

\section{Bibliography}

Applebaum Anne, Gułag, trans. Jakub Urbański, Świat Książki, Warsaw 2005.

Courtois Stephane, Werth Nicolas, Panne Jean-Louis, et al., Czarna księga komunizmu. Zbrodnie, terror, prześladowania, trans. Krzysztof Walkar, Andrzej Nieuważny, et al., Prószyński i S-ka, Warsaw 1999.

Figes Orlando, Szepty. Życie w stalinowskiej Rosji, trans. Władysław Jeżewski, Wydawnictwo Magnum, Warsaw 2008.

Golka Marian, Pamięć społeczna i jej implanty, Wydawnictwo Naukowe Scholar, Warsaw 2009.

Halbwachs Maurice, Społeczne ramy pamięci, trans. Marcin Król, Wydawnictwo Naukowe PWN, Warsaw 2008.

Kępiński Marcin, Pomiędzy pamięcia autobiograficzna a zbiorową. Polska Ludowa $i$ stan wojenny $w$ narracjach łódzkich nauczycieli, Wydawnictwo Uniwersytetu Łódzkiego, Łódź 2016.

Klimowicz Tadeusz, Przewodnik po wspótczesnej literaturze rosyjskiej i jej okolicach (1917-1996), Towarzystwo Przyjaciół Polonistyki Wrocławskiej, Wrocław 1996.

Le Goff Jacques, Historia i pamięć, trans. Anna Gronowska, Joanna Stryjczyk, Wydawnictwa Uniwersytetu Warszawskiego, Warsaw 2007.

Miłosz Czesław, Zniewolony umysł, Wydawnictwo Literackie, Kraków 1999.

Orwell George, Rok 1984, trans. Tomasz Mirkowicz, Państwowy Instytut Wydawniczy, Warsaw 1989.

Ricoeur Paul, Pamięć, historia, zapomnienie, trans. Janusz Margański, Universitas, Kraków 2007.

Saryusz-Wolska Magdalena, Traba Robert (eds.), Modi memorandi. Leksykon kultury pamięci, Wydawnictwo Naukowe Scholar, Warsaw 2015.

Szałamow Warłam, Opowiadania kołymskie, vol. II, trans. Juliusz Baczyński, Wydawnictwo ATEXT, Gdańsk 1991.

Szałamow Warłam, Wiszera. Antypowieść, trans. Juliusz Baczyński, Czytelnik, Warsaw 2000.

Szkoła Dawid, "Zakładniczka historii”, [in:] Zmiany, metamorfozy, rewolucje, Małgorzata Czapiga, Katarzyna Konarska (eds.), Wydawnictwo Uniwersytetu Wrocławskiego, Wrocław 2018. 
Śpiewak Paweł, Pamięć po komunizmie, Wydawnictwo słowo/obraz terytoria, Gdańsk 2005.

Wat Aleksander, Mój wiek. Pamiętnik mówiony. Rozmowy prowadzit i wstępem opa-

trzył Czesław Miłosz, part 1, Czytelnik, Warsaw 1990.

Marcin Kępiński

\title{
Mur milczenia, mur zamknięcia, mur wokół pamięci i literatury. Protezy Warłama Szałamowa jako metafora sowieckiego imperium
}

\author{
Streszczenie
}

Literatura o charakterze autobiograficznym nabiera szczególnego znaczenia w świecie krwawych i tragicznych wydarzeń XX wieku, Holokaustu, drugiej wojny światowej, rzeczywistości totalitaryzmów hitlerowskiego i sowieckiego, obozów śmierci i przymusowej pracy. To pamięć doznanej traumy, dezintegrującej tożsamość, doświadczeń egzystencjalnych o charakterze granicznym, o których autor - świadek epoki - czuje przymus mówienia.

Antropologiczna analiza opowiadania Warłama Szałamowa Protezy pozwala na uchwycenie roli pamięci oraz świadectwa autobiograficznego jako swoistego kulturowego i literackiego antidotum na milczenie oraz pamięć zafałszowaną przez totalitaryzm sowiecki.

Autor Opowiadań kołymskich wiernie przedstawia świat będący poza nawiasem świata „ludzkiego", prawie niemożliwy do opowiedzenia, ze względu na obecną w nim moralną nicość, przemoc i strach przed władzą. Władzą, która nakazuje zapomnieć o zbrodni, ofiarach i katach.

Słowa kluczowe: literatura, świadectwo, pamięć, zapomnienie, totalitaryzm, łagry 


\title{
The wall of silence surrounding literature and remembrance: Varlam Shalamov's Artificial Limbs, Etc. as a metaphor of the soviet empire
}

\author{
Summary
}

Literature of an autobiographical character acquires a special significance in the world of the bloody tragic events of the $20^{\text {th }}$ century, i.e. the Holocaust, the Second World War, the realities of the Nazi and Soviet totalitarianisms, death camps, and forced labour. Those are the recollections of experienced trauma which shatters identity, and of existential experiences of a borderline nature, of which Shalamov, a witness to the epoch, felt an obligation to talk.

An anthropological analysis of Varlam Shalamov's short story titled Artificial Limbs, Etc. enables one to grasp the role of memory and autobiographical testimony as a kind of cultural and literary antidote to silence and memory distorted by the Soviet totalitarianism.

The author of Kolyma Tales offered a faithful description of a world outside the 'human' world, one which was almost impossible to describe due to its inherent moral void, level of violence, and fear of the authorities who made people forget about the crimes, victims, and oppressors.

Keywords: literature, testimony, memory, forgetfulness, totalitarianism, GULAG

Marcin Kępiński - professor of the University of Lodz, Ph.D. hab.; head of the Department of Cultural Anthropology, Institute of Ethnology and Anthropology, University of Lodz. In his research, he focuses on symbolic anthropology, the social and cultural impact of the media, cultural images of war, anthropological literature, and the recollections of People's Poland and Martial Law. He published texts in journals such as "Kultura i Społeczeństwo", "Kultura i Historia", "Etnografia Polska", "Kultura i Wychowanie", and "Zeszyty Wiejskie", as well as in multiauthor monographs. He was the academic editor of the publication: Dwór. Ponowoczesne przygody idei i formy (Łódź 2016). Author of books: Mit, symbol, historia, tradycja. Gombrowicza gry z Kultura (Warsaw 2006), Podróż w ciemności. Kulturowe obrazy wojny (Łódź 2012), Pomiędzy pamięcia autobiograficzną a zbiorową. Polska Ludowa i stan wojenny w narracjach łódzkich nauczycieli (Łódź2016). 